RESEARCH ARTICLE

\title{
Growth variations of edaphic specialist species in a reciprocal pot experiment in Sri Lanka
}

\author{
S. Madawala Weerasinghe ${ }^{1 *}$, C. Chandrasekara ${ }^{2}$, G. Seneviratne ${ }^{3}$, C.V.S. Gunatilleke ${ }^{1}$ and I.A.U.N. \\ Gunatilleke ${ }^{1}$ \\ I Department of Botany, Faculty of Science, University of Peradeniya, Peradeniya. \\ 2 Postgraduate Institute of Science, University of Peradeniya, Peradeniya. \\ 3 Institute of Fundamental Studies, Hantana Road, Kandy.
}

Revised: 05 March 2010 ; Accepted: 13 May 2010

\begin{abstract}
Edaphic factors may determine the habitat associations shown by some tropical trees. In Sinharaja, a tropical rainforest in Sri Lanka, about $79 \%$ of tree species show habitat preferences. The present study attempted to investigate the role of edaphic factors in determining habitat specialization, using a reciprocal pot experiment with four edaphic specialist species (Agrostistachys hookeri, Semecarpus gardneri, Mesua nagassarium and Agrostistachys intramarginalis). Both Agrostistachys species showed increased growth rates and total biomass when grown in their native soils compared to that of non-native soils, while $M$. nagassarium showed a better growth in non-native soils. Higher biomass allocation to roots was evident in all species when they were grown in sandrich valley soil irrespective of their specialized soil type. No significant trend was observed in foliar nutrient concentrations when grown in native or non-native soils. The results suggest that edaphic factors play a vital role in the spatial distribution of Agrostistachys species. This is perhaps due to plants showing more acclimatory shifts when grown in their native soils compared to non-native soils. The results also suggest the importance of other factors such as plasticity, water-use efficiency and herbivory in the spatial distribution of plants.
\end{abstract}

Keywords: Agrostistachys hookerii, Agrostistachys intramarginalis, edaphic factors, habitat specialization, Mesua nagassarium, Sri Lanka.

\section{INTRODUCTION}

Early workers assumed that the high diversity associated with tropical forests is always accompanied by an even spatial distribution of species. However, later studies report that tropical tree species always show a certain degree of clumping rather than even distribution across the landscape ${ }^{1}$. Many factors contribute to the maintenance of species diversity in tropical rainforests ${ }^{2-4}$. Niche differentiation with respect to resource availability remains a prominent hypothesis to account for the maintenance of tree species diversity in tropical forests $^{5}$. One way of expressing resource-based niche differentiation is habitat specialization; different tree species are best suited to different habitats, where they are competitively dominant and relatively more abundant ${ }^{6}$. The importance of edaphic variables determining habitat associations of tree species has been stressed in previous studies ${ }^{7}$. To establish the relative contribution of habitat specialization to the maintenance of diversity in tropical forests, a rigorous quantification of vegetation and environmental parameters is required ${ }^{8}$.

It has been proposed that there may be sufficient heterogeneity in light and other physical factors in and around canopy gaps to explain the coexistence of tree species'. This is an example of the 'regeneration niche' hypothesis. In many plant communities, habitat partitioning is possible mostly at the seedling level, where habitats are more heterogeneous than those experienced by an adult plant ${ }^{9}$. There is substantial evidence to favour the habitat partitioning theory though its underlying mechanisms and processes are not yet identified precisely. Scientists have also focused on alternative hypotheses, many of which invoke the role of natural enemies in distance and density dependent mortality of juveniles and the disproportionate mortality of more abundant species. 
In contrast to the early thinking that tropical forest trees are evenly distributed throughout the landscape, later studies suggest that the distribution of trees may be influenced stongly by edaphic heterogeneity 9-12. A study ${ }^{6}$ found that $64 \%$ of species in a 50 -ha plot on Barro Colorado Island, Panama show significant habitat associations driven by edaphic factors. A comparative study carried out on three diverse neotropical forests (in Colombia, Ecuador and Panama) also concluded that belowground resource availability plays an important role in the assembly of $36-51 \%$ of species in tropical tree communities at a local scale ${ }^{13}$. Different approaches (mainly plot-based studies) have been undertaken by researchers to find out whether species distributions are significantly correlated with edaphic factors ${ }^{6,14,15}$. In most instances, where spatial variation in the abundance of species of trees has been studied, associations have been found with different habitat variables and their interactions with the biotic environment ${ }^{1,16}$. Studies have shown that species distribution was strongly correlated with variations in topography and other edaphic factors such as soil moisture and nutrient status 9, 12, 13, 17-19. In support of these findings, a study ${ }^{20}$ showed that $60 \%$ of the tree species in a 52-hectare plot at Lambir, Malaysia, have spatial distributions biased across the edaphic and topographic gradient. Some of the most plausible edaphic factors driving this non-random distribution of trees in the tropics may include soil drainage, nutrient availability and soil texture ${ }^{21-24}$. A study carried out in the Peruvian Amazon ${ }^{25}$ has shown that herbivore pressure also could promote habitat specialization. However, in spite of all these studies, there are many unanswered questions on the role of habitat heterogeneity in maintaining high tree species richness in tropical rain forest ecosystems. To address some of these controversies, rigorous testing of habitat-related spatial aggregation in tropical forest communities is required, in order to provide experimental verification that tree species perform better in habitats in which they are aggregated. A previous study ${ }^{20}$ also stressed the importance of gathering evidence to determine the performance of plants when they are exposed to native soils compared to non-native soils.

The 25-ha Forest Dynamic Plot (FDP) in Sinharaja is located within the lowland rainforest zone and has an elevation range from 424 to 575 m.a.s.l. The structure and floristic composition of the Sinharaja FDP show an interesting correlation across a small scale altitudinal gradient of $151 \mathrm{~m}^{26}$. Based on the spatial heterogeneity of three physical parameters; viz. elevation, slope, and convexity, eight different topographic habitats were identified within the plot. Of the 125 tree species tested, 99 species showed at least one positive or negative association (specialists) to one or more of the habitats identified $^{26}$. Other tree species showed no special habitat preferences (generalists) and were distributed more or less evenly throughout the landscape. The Sinharaja FDP provides an appropriate site to investigate soil-related habitat specialization exhibited by some of these tropical tree species along this small scale elevational gradient. The present study attempted to examine whether soilrelated factors may have contributed to species-habitat association, by carrying out a pot experiment with two valley-dominant (Agrostistachys hookerii and Semecarpus gardneri) and two ridge-dominant (Mesua nagassarium and Agrostistachys intramarginalis) species. Seedlings of all four species were grown in their native soil as well as in non-native soils to test whether species have soil-related performance differences in accord with their spatial distributions in the natural forest. We hypothesize that seedlings of the four forest species will grow faster in their native soils than in non-native soils.

\section{METHODS AND MATERIALS}

Site description: The pot experiment was conducted in a specially constructed plant house at the Research Station in the Sinharaja World Heritage Site $\left(6^{\circ} 21-26^{\prime} N\right.$, $80^{\circ} 21-34^{\prime} \mathrm{E}$; hereafter known as Sinharaja) located in the ever-wet south west lowlands of Sri Lanka. On a regional scale Sinharaja represents a mixed dipterocarp forest ${ }^{27}$ and locally it is classified as a Mesua-Doona community. The mean annual rainfall at Sinharaja is $5016 \mathrm{~mm}$ and it varies from 4080 to $5907 \mathrm{~mm}^{28}$. The annual minimum and maximum temperatures are 22 and $28{ }^{\circ} \mathrm{C}$, respectively. The highest monthly temperatures are observed in April $\left(25.3^{\circ} \mathrm{C}\right)$, May $\left(25.9^{\circ} \mathrm{C}\right)$ and

Table 1: Variation in some soil chemical and physical characteristics (at 0-20 $\mathrm{cm}$ depth) of the ridge and valley at the Sinharaja FDP in Sri Lanka.

\begin{tabular}{lcc}
\hline & \multicolumn{2}{c}{ Mean elevation } \\
\cline { 2 - 3 } Soil parameter & $\begin{array}{c}\text { Ridge } \\
(>525 \mathrm{~m})\end{array}$ & $\begin{array}{c}\text { Valley } \\
(<470 \mathrm{~m})\end{array}$ \\
\hline Total C (\%) & $3.24(0.22) \mathrm{a}$ & $2.48(0.14) \mathrm{b}$ \\
$\mathrm{pH}$ & $4.42(0.13) \mathrm{a}$ & $4.54(0.11) \mathrm{a}$ \\
Extractable P $(\mu \mathrm{g} / \mathrm{g}$ soil $)$ & $1.94(0.13) \mathrm{b}$ & $2.79(0.22) \mathrm{a}$ \\
Total N $(\%)$ & $1.61(0.1) \mathrm{b}$ & $2.13(0.2) \mathrm{a}$ \\
Clay $(\%)$ & $21.0(5.99) \mathrm{a}$ & $11.4(0.79) \mathrm{b}$ \\
C:N ratio & $22.1 \quad(2.24) \mathrm{a}$ & $12.8 \quad(1.59) \mathrm{b}$ \\
Water potential $(\mathrm{kPa}) *$ & & \\
Wet season & $-30 \quad(11.7)$ & $-96(81.2)$ \\
Dry season & $-525(253.4)$ & $-118(80.8)$ \\
\hline
\end{tabular}

* Soil water potentials were measured using the Filter Paper method. Standard error of the mean (SEM) is given within parentheses. Different letters indicate significant differences $(p=0.05)$ between the two elevation levels. 
January $\left(25.1^{\circ} \mathrm{C}\right)$ and it is least in December $\left(23.8^{\circ} \mathrm{C}\right)^{28}$. Sinharaja also experiences a high annual temperature which is typical of the tropics with little seasonal variation and marked daily changes. The detailed information on floristic richness and diversity within the FDP has been given in Gunatilleke et al. ${ }^{29}$.

Soil nutrient status: Some selected chemical and physical factors of soil on the FDP at Sinharaja are given in Table $1^{30}$. The 'ridge' soils contain significantly higher clay $(21 \%)$ and soil organic carbon (C) concentrations $(3.24 \%)$ than the 'valley' soils. In contrast to this trend, total nitrogen $(\mathrm{N})$ and extractable phosphorus (P) concentrations were significantly higher in the valley soils compared to ridge soils. Soil $\mathrm{pH}$ did not show any significant difference between ridge and valley soils. A separate soil study that has been conducted in Sinharaja has shown that valley soils have significantly higher $\mathrm{pH}$ and concentrations of total $\mathrm{N}$ and magnesium $(\mathrm{Mg})$ than ridge soils ${ }^{31}$.

Test species: Agrostistachys intramarginalis (Euphorbiaceae) is a large shrub or treelet growing up to $7 \mathrm{~m}$ in height. It is an endemic to Sri Lanka and found in the understory tree layer in the Sinharaja forest. A. hookeri (Euphorbiaceace) is an understory shrub and also an endemic to Sri Lanka. Mesua nagassarium (Clusiaceae) is a native canopy tree. Semecarpus gardneri belongs to the family Anacardiaceae and is an endemic to Sri Lanka. It is commonly found in the sub-canopy layer of the Sinharaja forest.

Experimental design: In the cross-over pot experiment, the plants were subjected to two treatments, i. e. grown in their native as well as in their non-native soils. Seedlings in the two-leaved growth stage were collected from each species from their naturally growing habitats in the forest. For the pot experiment soil was collected from three randomly selected sites from the ridge and from the valley sites within the 25 ha FDP. At each site, top soil was collected to a depth of about $15-20 \mathrm{~cm}$ and sub soil was collected from $20-35 \mathrm{~cm}$ depth separately. To prepare the potting medium, first, gravel particles were manually removed and then the soil from the different depths and from the ridge and the valley sites were separately mixed with sand in a ratio of $1: 1$. As the soils are very clayey in nature, sand was added in order to improve the texture. These soil-sand mixtures were then filled into black polythene bags $(15.2 \mathrm{~cm} \times 30.5 \mathrm{~cm}, 300$ gauge); each poly bag contained approximately $3 \mathrm{~kg}$ of soil. Twenty five seedlings as replicates from each test species were then potted either in their native or nonnative soil-containing poly bags. In total, 200 seedlings were planted (4 species x 2 soil types x 25 replicates). Transplanted seedlings were allowed to establish for about a week, dead seedlings were replaced and poly bags were arranged in a completely randomized design inside the shade house (covered with coir mats) at the Sinharaja field station. The seedlings received sun flecks that penetrate through the coir mat which mimics somewhat comparable conditions on the forest floor. The experiment was set up in January 2004 and maintained for about 18 months. Poly bags were randomly rearranged within the shade house four times during the experimental period to avoid any growth variations due to edge effects.

Data collection and analysis: Ten seedlings were randomly selected to determine fresh and dry mass at the time of planting. Foliar nutrient concentrations and mycorrhizal colonization were determined using 10 randomly selected seedlings at the start (to determine the initial foliar nutrient concentrations and mycorrhizal colonization) and after 18 months of growth under experimental conditions. Tissue nutrient concentrations were determined on an oven-dried sub sample of seedlings from each treatment. Tissue samples were wet digested and analyzed for $\mathrm{N}$ and $\mathrm{P}$ concentrations using Kjeldhal and molybdate-blue methods, respectively ${ }^{32}$. Mycorrhizal colonization was determined using the Phillips and Hayman method ${ }^{33}$.

After 18 months of growth (July 2005), harvested seedlings were separated into above- and below-ground components, dried at $70{ }^{\circ} \mathrm{C}$ to a constant weight, and weighed to a precision of $1 \mathrm{mg}$. Based on biomass measurements, root mass ratio (RMR) (root biomass as a fraction of the total biomass) were calculated ${ }^{34}$. The relative growth rate (RGR) was determined using the following equation. Average initial seedling dry mass was used to compute the relative growth rates at the final harvest (after 18 months).

$\mathrm{RGR}=\left(\log _{\mathrm{e}} \mathrm{m}_{2}-\log _{\mathrm{e}} \mathrm{m}_{1}\right) / \mathrm{t}_{2}-\mathrm{t}_{1}$

where $\mathrm{m}_{1}$ and $\mathrm{m}_{2}$ represent the dry masses $(\mathrm{g})$ at planting date $\left(\mathrm{t}_{1}\right)$ and harvested date $\left(\mathrm{t}_{2}\right)$, respectively. The data were analyzed using an un-paired t-test for each species separately to determine how RGR differed between seedlings grown in native and non-native soils. The analyses were conducted using MINITAB Release 14.30 statistical software.

\section{RESULTS}

\section{Survival of seedlings}

The mycorrhizal colonization tests revealed that seedlings were not colonized by mycorrhizae either at 
Table 2: Percentage seedling survival rates after 18 months of growth of four tree species in Sinharaja, based on 25 seedlings per species per treatment.

\begin{tabular}{lccc}
\hline \multirow{2}{*}{ Species } & \multicolumn{3}{c}{ Survival (\%) } \\
\cline { 2 - 4 } & Native soil & $\begin{array}{c}\text { Non-native } \\
\text { soil }\end{array}$ & Difference \\
\hline A. hookerii $(\mathrm{Vd})$ & 67 (valley) & 61 (Ridge) & 6 \\
S. gardneri $(\mathrm{Vd})$ & 16 (valley) & 11 (Ridge) & 5 \\
& & & \\
A. intramarginalis $(\mathrm{Rd})$ & 84 (ridge) & 83 (Valley) & 1 \\
M. nagassarium $(\mathrm{Rd})$ & 72 (ridge) & 89 (Valley) & 17 \\
\hline
\end{tabular}

$\mathrm{Vd}=$ valley dominant $; \mathrm{Rd}=$ ridge dominant

the start of the experiment or after 18 months of growth under experimental conditions. Varying survival rates between test plants do not provide any convincing differences to demonstrate that soil specificity does contribute to survival of seedlings (Table 2). Both ridge dominants species (A. intramarginalis and M. nagassarium) showed higher survival rates (> 72\%) than the valley dominants, A. hookeri (61-67\%) and S. gardneri (11-16\%). S. gardneri had the lowest survival rates in both native (16\%) and non-native (11\%) soil types; hence it was excluded from further analyses. However, M. nagassarium showed fairly notable chance of survival in the non-native soil compared to native soil (17\% difference).

\section{Relative growth rate}

A. hookeri showed significantly higher (19\%) relative growth rate (RGR) when grown in native soils compared to non-native (Figure 2). A. intramarginalis also showed $25 \%$ higher growth in its native soil though the difference was not significant at $\mathrm{p}=0.05$. However, $M$. nagassarium has shown a significantly better growth (33\%) in nonnative soils than in native soil.

\section{Total biomass}

The total biomass of $A$. hookeri (valley dominant: Vd) at harvest was $19 \%$ higher in valley soils than that in ridge soils, though the difference was not significant $(\mathrm{p}=0.122)$. Similarly, A. intramarginalis (ridge dominate, $\mathrm{Rd}$ ) showed a significantly higher total biomass in seedlings grown in ridge soil than that in valley soil $(\mathrm{p}=0.044)$. Unlike the two Agrostistachys species, Mesua, a ridge species ( $\mathrm{Rd})$, gained a significantly higher biomass when it was grown in its non-native valley soil $(p=0.036)$ (Figure 3).

\section{Biomass allocation pattern}

In all three species, the root weight ratio (RWR) was higher in the seedlings grown in valley soil than those in the ridge soil and this difference was significantly greater in both A. hookerii and M. nagassarium (Figure 4; $\mathrm{p}$ values are 0.035 and 0.0003 , respectively).

\section{Foliar nutrient concentrations}

The initial plant nitrogen $(\mathrm{N})$ and phosphorus $(\mathrm{P})$ concentrations of $A$. hookeri, A. intramarginalis and $M$. nagassarium varied significantly between species. The plant $\mathrm{N}$ and $\mathrm{P}$ concentrations were significantly higher in $A$. hookeri $(\mathrm{Vd})$ than in the two ridge dominants, A. intramarginalis and M. nagassarium (Table 3). However, the shoot and root $\mathrm{N}$ and $\mathrm{P}$ concentrations in all three species measured at the time of the final harvest (after 18 months of growth) did not vary significantly irrespective of whether they had grown in their native or non-native soil types (Figure 5).

In both A. hookeri and M. nagassarium, shoot and root nutrient concentrations decreased significantly during the course of their growth, while $A$. intramarginalis showed a slight increase in foliar nutrient concentrations after 18 months of growth, irrespective of the soil medium.

\section{DISCUSSION}

The survival variations shown by the seedlings in the present study are possibly due to their varying abilities to adjust to new surroundings under shade house conditions. The poor growth and high mortality rates of

Table 3: Initial shoot and root nutrient contents of A. hookeri, A. intramarginalis and M. nagassarium. One-way ANOVA: different letters indicate significant differences between species at $5 \%$ probability level.

\begin{tabular}{llccc}
\hline Species & Plant part & $\begin{array}{c}\text { A. hookeri } \\
(\mathrm{Vd})\end{array}$ & $\begin{array}{c}\text { A. intramarginalis } \\
(\mathrm{Rd})\end{array}$ & $\begin{array}{c}\text { M. nagassarium } \\
(\mathrm{Rd})\end{array}$ \\
\hline $\mathrm{N}(\%)$ & shoot & $1.76^{\mathrm{a}}$ & $0.71^{\mathrm{c}}$ & $1.06^{\mathrm{b}}$ \\
& root & $1.38^{\mathrm{a}}$ & $0.67^{\mathrm{b}}$ & $0.53^{\mathrm{b}}$ \\
$\mathrm{P}(\%)$ & shoot & $0.47^{\mathrm{a}}$ & $0.07^{\mathrm{b}}$ & $0.12^{\mathrm{b}}$ \\
& root & $0.36^{\mathrm{a}}$ & $0.05^{\mathrm{b}}$ & $0.16^{\mathrm{c}}$ \\
\hline
\end{tabular}


Semecarpus may be attributed to its inability to adapt to new environmental conditions inside the shade house. Studies have shown that survival and growth of rainforest seedlings rely on plasticity (ability to adjust to varying environmental conditions) and mycorrhizal colonization during their early establishment phase under both natural and simulated conditions ${ }^{35,36}$. However, in the present experiment none of the species showed noteworthy home-soil advantage in their survival rates when grown in native and non-native soils. Observations also revealed that none of the test seedlings were infected with mycorrhizae during the experimental period. Therefore, the present results did not give any indication to suggest that the survival rates associate with their choice of habitat or else with mycorrhizal colonization. Previous studies ${ }^{20,37}$ also have shown no unequivocal relationships between soil specificity and survival (or mortality). However, in the present study, M. nagassarium, which is a ridge dominant, survived markedly better in valley soils than in the ridge soils indicating its ability to take the advantage of better quality soils (nutrient-rich valley soils) than other test species. The high plastic ability of M. nagassarium when exposed to shade and drought conditions has been demonstrated in an experiment conducted under shade house conditions ${ }^{38}$.

The two Agrostistachys species with differing soildominance grew faster in their native soils than in the non-native soils. This trend was evident in terms of their RGR and total biomass indicating that for Agrostistachys
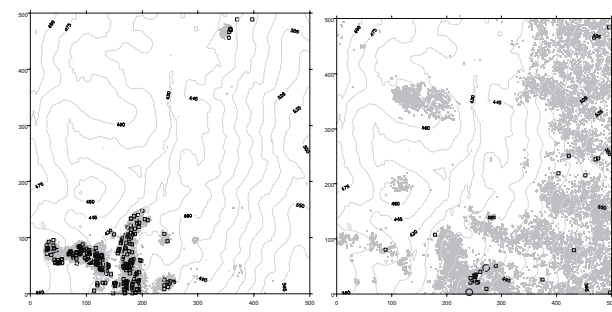

(a)

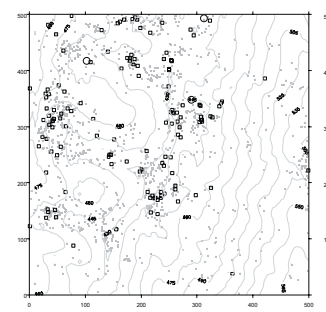

(c)

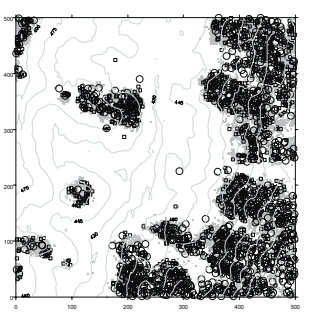

Figure 1: Spatial distribution maps of the four species selected for the study. (a) A. hookeri (valley dominant, Vd), (b) A. intramarginalis (ridge dominant, Rd), (c) S. gardneri (Vd) and (d) M. nagassarium (Rd). species edaphic factors do play a vital role in habitat preferences. A reciprocal experiment conducted in Sepilok Forest Reserve, Borneo ${ }^{7}$ showed that edaphic specialist species, when grown on their native soils, are capable of acclimatory shifts to achieve resource-use efficiency than species not specialized to that soil type. In the present study, $A$. intramarginalis performed better in its less fertile native ridge soils than fertile valley soils, indicating its high plastic ability (morphologically and/ or physiologically) in less fertile soils to compensate for their overall growth. According to one study ${ }^{39}$, plasticity is a morphological (and physiological) trait shown by some plants in response to edaphic variations that could be driven by scarcity of nutrients and/or water. The results suggest that being plastic, $A$. intramarginalis has higher chances of acclimatory shifts in order to accomplish resource-use efficiency under low-fertile soil conditions.

M. nagassarium on the other hand showed no growth preference in their native soils; in fact growing significantly well under non-native soils. Two studies ${ }^{37,40}$ have also observed that plants do not always grow faster and better on their native soils than in non-native soils. Another study ${ }^{40}$ has suggested that the differing responses of plants to different soil types is mainly due to their inherent growth rates rather than responding

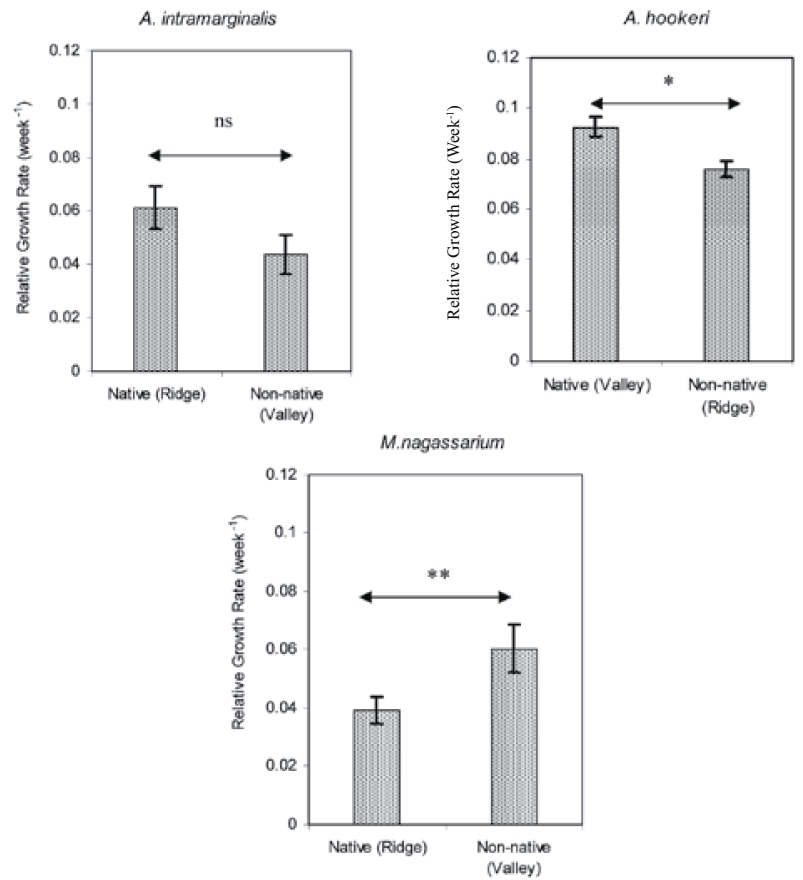

Figure 2: Relative Growth Rates (RGR) of $A$. intramarginalis, A. hookeri and M. nagassarium in their native and nonnative soils. Untransformed data were used to plot the graph. Vertical bars indicate the standard errors of the mean (SEM). 

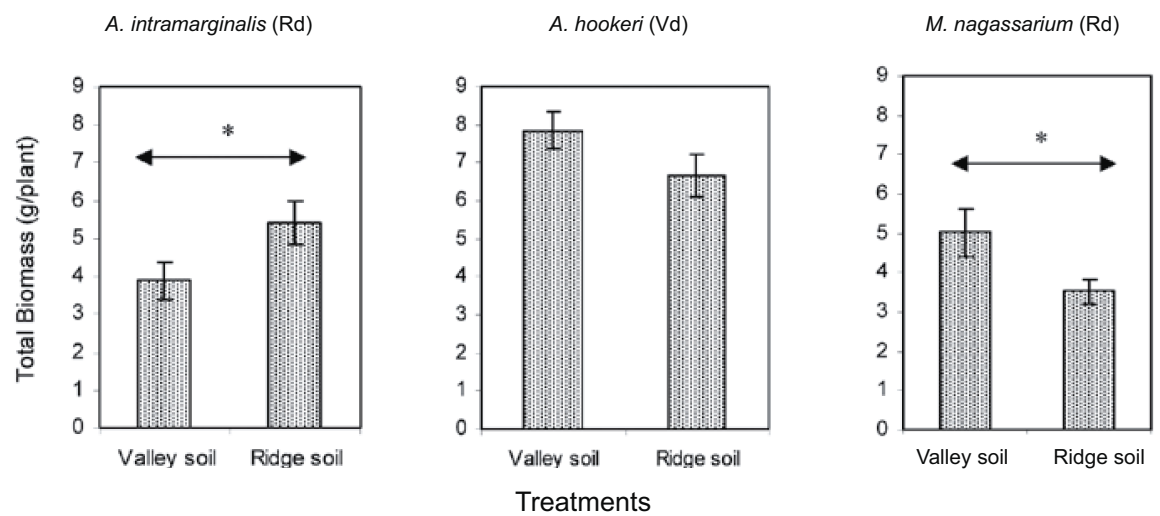

Figure 3: Total biomass of ridge-dominant and valley-dominant species on each soil type. Vertical bars indicate the standard error of the mean (SEM). Asterisks show significant differences between the two soil types at $5 \%$ probability level.
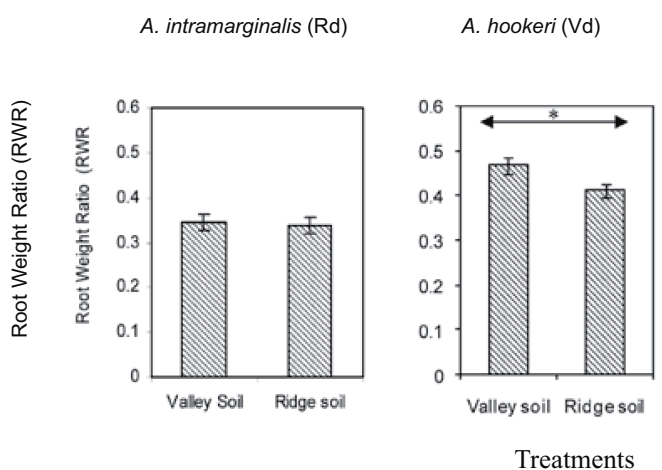

M. nagassarium $(\mathrm{Rd})$

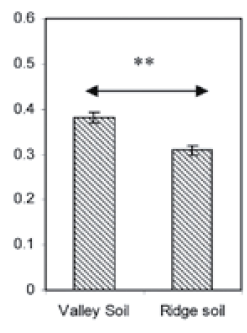

Figure 4: Root Weight Ratio (RWR) of ridge dominant (Rd) and valley dominant (Vd) species on each soil type. Vertical bars indicate the standard error of the mean (SEM).

to changes in soil quality. Therefore, our results also imply that not all plants always perform better in their home-soils than on non-home soils. These ambiguous results indicate that it is not only the edaphic factors that will determine plant distribution, but also other factors such as competition, herbivory, and climatic factors. A study ${ }^{37}$ has also concluded that there may be potential mechanisms influencing the spatial distribution pattern of plant species other than soil nutrient availability. Some of these potential mechanisms are dispersal limitations and light, which are important unmeasured sources of variations and beyond the scope of this study. A previous study $^{41}$ also stresses the importance of combination of factors when determining the spatial distribution of plants.

Seedlings of A. hookeri and M. nagassarium have shown greater biomass allocation to roots when grown in the nutrient-rich valley soils, irrespective of their home-soil preferences. Their enhanced root allocations correlate with their better performances irrespective of their native habitats indicating increased nutrient assimilation when roots come across nutrient-rich soils. Evidence also suggests that plant roots tend to proliferate in contact with high-nutrient soils thereby increasing assimilation rates ${ }^{42-44}$. Nutrient availability perhaps is not the only reason for $A$. hookeri and M. nagassarium to produce more roots in valley soils than in ridge soils. The sandy nature of the valley soil allows easy penetration of the roots deep into the soil and easy spreading compared to clay-rich soil. The anoxic conditions created in the rooting zone due to the greater water holding capacity in the clay-rich ridge soil may be another reason for relatively lower allocation of biomass to the root system than to the shoot in ridge soil.

The higher initial concentrations of foliar $\mathrm{N}$ and $\mathrm{P}$ in the valley dominant $A$. hookeri are consistent with 

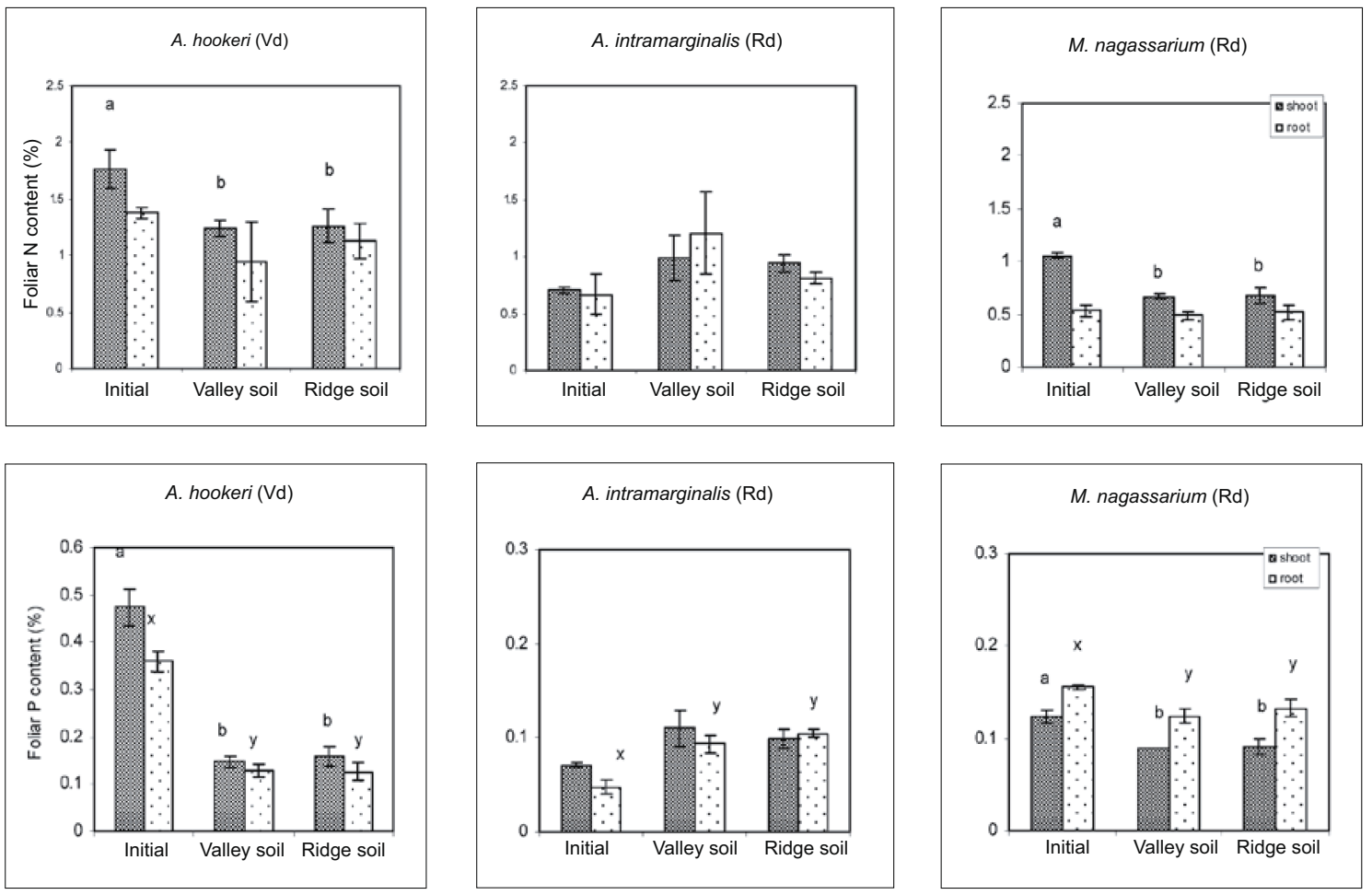

Figure 5: Foliar $\mathrm{N}$ and $\mathrm{P}$ concentrations in roots and shoots of A. hookeri, A. intramarginalis and M. nagassarium (initial and after 18 months of growth). Different letters indicate significant differences at $5 \%$ probability level. Vertical bars indicate standard error of the mean (SEM).

high $\mathrm{N}$ and $\mathrm{P}$ concentrations in the valley soils. However, the foliar nutrient concentrations did not directly reflect the soil nutrient status always, as factors other than soil nutrient availability would also determine the foliar nutrient levels in plants. Concentrations of $\mathrm{N}$ and $\mathrm{P}$ did not differ between plants grown in valley and ridge soils for any of the three species after 18 months of growth in their respective native and non-native soils. Therefore, present observations did not give us an opportunity to relate the performance differences in plants to their tissue nutrient concentrations directly. One study ${ }^{20}$ suggested that differential growth responses of seedlings of some rainforest species were not related to soil nutrient availability and that the reduced growth of seedlings in their non-native soil may have resulted from occasional anoxic conditions in the rooting zone due to clay-rich soils, the absence of native mycorrhizal flora, and the toxic effects due to high Aluminium $(\mathrm{Al})$ or Iron $(\mathrm{Fe})$ concentrations, etc.

Out of the four species studied, two Agrostistachys species with different soil preferences, performed better when grown in their respective native soil types indicating that edaphic factors seem to have influenced the growth of plants and consequently the habitat associations. M. nagassarium did not follow this trend and in fact performed even better when grown in nonnative soils. From the present results, we could suggest that the performance variations of plants are not only determined by edaphic resources, but also by their inherent eco-physiological traits such as plasticity and other environmental factors.

A previous study ${ }^{45}$ suggest that the spatial distribution of 'habitat specialists' are governed by environmental factors while the distribution of 'habitat generalists' are governed by dispersal processes, though these facts cannot be fully supported or disputed by the findings of the present study. However, it would be imperative to carry out long-term research in the natural environment taking into consideration other parameters such as competition, light, moisture content, understorey and forest gap environments in order to set more light on the underlying factors that eventually decide the spatial distribution of plant species with and without habitat preferences (habitat 'specialists' and 'generalists' respectively). The seedling growth should also be evaluated until at least the seedlings become saplings, as the trees give more information on their preferential traits at the mature stage than at the seedling stage. 


\section{Acknowledgement}

Authors express their sincere gratitude to the Asia Programme of the Center for Tropical Forest Science, Smithsonian Institute, USA for providing financial assistance to conduct this experiment. Thanks also due to Mr. Anura Tennakoon, Technical Officer, for the support given during the establishment and maintenance of the pot experiments conducted at the Research Station in Sinharaja.

\section{References}

1. Condit R., Ashton P.S., Baker P., Bunyavejehewan S., Gunatilleke S., Gunatilleke N., Hubbell S.P., Foster R.B., Itoh A., LaFrankie J.V., Lee H.S., Losos E., Manokaran N., Sukumar R. \& Yamakura T. (2000). Spatial patterns in the distribution of tropical tree species. Science. 288: 1414-1418.

2. Wills C., Condit R., Foster B. \& Hubbell S.P. (1997). Strong density- and diversity-related effects help to maintain tree species diversity in a neotropical forest. Proceedings of the National Academy of Sciences, USA 94: 1252-1257.

3. Hubbell S.P. (2001). The Unified Theory of Biodiversity and Biogeography. Princeton University Press, USA.

4. Paoli G.D., Curran L.M. \& Slik J.W.F. (2008). Soil nutrients affect spatial patterns of aboveground biomass and emergent tree density in Southwestern Borneo. Oecologia 155: 287-299.

5. Connell J.H. (1978). Diversity in tropical rain forests and coral reefs. Science 199: 1302-1309.

6. Harms K.E., Condit R., Stephen P., Hubbell S.P. \& Foster R.B. (2001). Habitat associations of trees and shrubs in a 50-ha neotropical forest plot. Journal of Ecology 89: 947959.

7. Baltzer J.L., Thomas S.C., Nilus S. \& Burslem D.F.R.P. (2005). Edaphic specialization in tropical trees: physiological correlates and responses to reciprocal transplantation. Ecology 86(11): 3063-3077.

8. Burslem D.F.R.P., Grubb P.J. \& Turner I.M. (1995). Responses to nutrient addition among shade-tolerant tree seedlings of lowland tropical rain forest in Singapore. Journal of Tropical Ecology 83: 113-122.

9. Webb C.O. \& Peart D.R. (2000). Habitat associations of trees and seedlings in a Bornean rain forest. Journal of Ecology 88: 464-478.

10. Lescure J.P. \& Boulet R. (1985). Relationships between soil and vegetation in a tropical rainforest in French Guiana. Biotropica 17(2): 155-164.

11. Itoh A., Yamakura T., Ohkudo T., Kanzaki M., Palmiotto P.A., Lafrankie J.V., Ashton P.S. \& Lee H.S. (2003). Importance of topography and soil texture in the spatial distribution of two sympatric dipterocarp trees in Bornean rainforest. Ecological Research 18: 307-320.

12. Poulsen A.D., Tuomisto H. \& Balslev H. (2006). Edaphic and floristic variation within a 1-ha plot of lowland Amazonian Rain Forest. Biotropica 38(4): 468-478.
13. John R., Dalling J.W., Harms K.E., Yavitt J.B., Stallard R.F., Mirabello M., Hubbell S.P., Valencia R., Navarrete H., Vallejo M. \& Foster R.B. (2007). Soil nutrients influence spatial distributions of tropical tree species. Proceedings of the National Academy of Sciences, USA 104 (3): $864-869$.

14. Potts M.D., Ashton P.S., Kaufman L.S. \& Plotkin J.B. (2002). Habitat patterns in tropical rainforests: a comparison of 105 plots in northwest Borneo. Ecology 83: 2782-2797.

15. Plotkin J.B., Potts M.D., Leslie N., Manokaran N., Lafrankie J. \& Ashton P.S. (2000). Species-area curves, spatial aggregation, and habitat specialization in tropical forests. Journal of Theoretical Biology 207: 81-99.

16. Hubbell S.P. (1979). Tree dispersion, abundance and diversity in a tropical dry forest. Science 203: 1299-1309.

17. Clark D.B., Clark D.A. \& Read J.M. (1998). Edaphic factors and the landscape-scale distributions of tropical rainforest trees. Ecology 80: 2662-2675.

18. Swaine M.D. (1996). Rainfall and soil fertility as factors limiting forest species distributions in Ghana. Journal of Ecology 84(3): 419-428.

19. Svenning J.C. (2001). On the role of microenvironmental heterogeneity in the ecology and diversification of neotropical rainforest palms (Areacaceae). Botanical Review 67: 1-53.

20. Palmiotto P.A., Davies S.J., Vogt K.A., Ashton M.S., Vogt D.J. \& Ashton P.S. (2004). Soil-related habitat specialization in dipterocarp rain forest tree species in Borneo. Journal of Ecology 92: 609-623.

21. Thomas S.C. (2003). Comparative biology of tropical trees: a perspective from Pasoh. In: Ecology of a Lowland Rainforest in Southeast Asia (Eds. T. Okuda, N. Manokaran, Y. Matsumoto, K. Niiyama, S.C. Thomas \& P.S. Ashton). Springer-Verlag, Japan.

22. Gartlen J.S., Newbery D.M., Thomas D.W. \& Waterman P.G. (1986). The influence of topography and soil phosphorus on vegetation of Korup Forest reserve, Cameroon. Vegetatio 65: 131-148.

23. Baillie I.C., Ashton P.S., Court M.N., Anderson J.A.R., Fitzpatrick E.A. \& Tinsley J. (1987). Site characteristics and distribution of tree species in a mixed dipterocarp forest on tertiary sediments in central Sarawak, Malaysia. Journal of Tropical Ecology 3: 201-220.

24. Davies S.J., Palmiotto P.A., Ashton P.S., Lee H.S., \& LaFrankie J.V. (1998). Comparative ecology of 11 sympatric species of Macaranga in Borneo: tree distribution in relation to horizontal and vertical resource heterogeneity. Journal of Ecology 86: 662-673

25. Fine P.V.A., Mesones I. \& Coley P.D. (2004). Herbivores promote habitat specialization by trees in Amazonian forests. Science 305: 663-665.

26. Gunatilleke C.V.S., Gunatilleke I.A.U.N., Esufali S., Harms K.E., Ashton P.M.S., Burslem D.F.R.P. \& Ashton P.S. (2006). Species-habitat associations in a Sri Lankan dipterocarp forest. Journal of Tropical Ecology 22:371384.

27. Whitmore T.C. (1984). Tropical Rain Forests of the Far East ( $2^{\text {nd }}$ edition). Oxford University Press, Oxford, UK. 
28. Munidasa B.K.H., Gunatilleke C.V.S. \& Gunatilleke I.A.U.N. (2002). Climate of Sinharaja rain forest, Sri Lanka: an attempt to understand the el-nino and la-nina events. Ceylon Journal of Science (Biological Sciences) 30: $37-54$

29. Gunatilleke C.V.S., Gunatilleke I.A.U.N., Ethugala A.U.K. \& Esufali S. (2004). Ecology of Sinharaja Rain Forest and the Forest Dynamics Plot in Sri Lanka's Natural World Heritage Site. WHT Publications (Pvt) Ltd, 95. Cotta Road, Colombo 8.

30. Chandrasekera C.M.C.P., Madawala Weerasinghe H.M.S.P., Gunatilleke I.A.U.N. \& Senevirathne G. (2005). Spatial distribution of arbuscular mycorrhizas along an elevational and edaphic gradient in the forest dynamic plot at Sinharaja, Sri Lanka. Ceylon Journal of Science (Biological Sciences) 34: 47-67.

31. Gunatilleke C.V.S., Perera G.A.D., Ashton P.M.S., Ashton P.S. \& Gunatilleke I.A.U.N (1996). Seedling growth of Shorea section Doona (Dipterocarpaceae) in soils from topographically different sites of Sinharaja forest in Sri Lanka. In: Tropical Tree Seedling Ecology (Ed. M.D. Swaine), UNESCO/Parthenon, Paris.

32. Anderson J.M. \& Ingram J.S.I. (1998). Tropical Soil Biology and Fertility. A Handbook of Methods. CABI Publishers, UK.

33. Phillips J.M. \& Hayman D.S. (1970). Improved procedure of clearing roots and staining parasitic and vesiculararbuscular mycorrhizal fungi for rapid assessment of infection. Transactions of the British Mycological Society 55:159-61.

34. Hunt R. (1978). Plant Growth Analysis. Edward Arnold Publishers Ltd., London.

35. Turjaman M., Tamai Y., Santoso E., Osaki M. \& Tawaraya K. (2006). Arbuscular mycorrhizal fungi increased early growth of two nontimber forest product species Dyera polyphylla and Aquilaria filaria under greenhouse conditions. Mycorrhiza 16(7): 459 - 464.

36. Guadarrama P., Álvarez-Sánchez J. \& Briones O. (2004).
Seedling growth of two pioneer tropical tree species in competition: The role of arbuscular mycorrhizae. Euphytica 138: $113-121$.

37. Russo S.E., Davies S.J., King D.A. \& Tan S. (2005). Soil - related performance variation and distributions of tree species in a Bornean rain forest. Journal of Ecology 93: 879-889.

38. Ashton M.S., Singhakumara B.M.P. \& Gamage H.K. (2006). Interaction between light and drought affect performance of Asian tropical tree species that have differing topographic affinities. Forest Ecology and Management 221: $42-51$.

39. Dent D.H. \& Burslem D.F.R.P. (2009). Performance trade-offs driven by morphological plasticity contribute to habitat specialization of Bornean tree species. Biotropica 41(4): $424-434$.

40. Brenes-Arguedas T., Rios M., Rivas-Torres G., Blundo C., Coley P.D. \& Kursar T.A. (2008). The effect of soil on the growth performance of tropical species with contrasting distributions. Oikos 117(10): $1453-1460$.

41. Esler K.J. \& Cowling R.M. (1993). Edaphic factors and competition as determinants of pattern in South African karoo vegetation. South African Journal of Botany 59(3): $287-295$.

42. Hodge A. (2004). The plastic plant: root responses to heterogeneous supplies of nutrients. New Phytologist 162: (1) 9-24.

43. Goss M.J., Miller M.H., Bailey L.D. \& Grant C.A. (1993). Root growth and distribution in relation to nutrient availability and uptake. European Journal of Agronomy 2: 57-67.

44. Bloom A.J., Chapin F.S. III \& Mooney H.A. (1985). Resource limitation in plants - an economic analogy. Annual Review of Ecology and Systematics 16: 363-392.

45. Pandit S.N., Kolasa J. \& Cottenie K. (2009). Contrasts between habitat generalists and specialists: an empirical extension to the basic metacommunity framework. Ecology 90(8): 2253 - 2262. 